\title{
ПОЧВЕННЫЙ ПОКРОВ ЮГА ЛЕСОСТЕПИ СРЕДНЕРУССКОЙ ВОЗВЫШЕННОСТИ НА ФОНЕ ВНУТРИВЕКОВЫХ КЛИМАТИЧЕСКИХ ИЗМЕНЕНИЙ
}

\author{
(C) 2016 г. Л. Г. Смирнова, Н. С. Кухарук, Ю. Г. Чендев \\ Белгородский государственный национальный исследовательский университет, 308015, Белгород, ул. Победы, 85 \\ e-mail: lidya.smirnova@yandex.ru \\ Поступила в редакцию 16.10.2015 г.
}

\begin{abstract}
Для изучения ответной реакции зональных почв и почвенного покрова лесостепи на изменения климата с помощью методов повторных почвенных обследований были разработаны методические подходы и алгоритмы, позволяющие проанализировать индикаторы короткопериодических климатических изменений в виде отдельных трансформаций почвенного покрова, происходящих на юге лесостепи Среднерусской возвышенности. С помощью ГИС-технологий выполнены векторные карты территории исследования и составлены базы данных почвенных ареалов. За период между двумя турами крупномасштабного почвенного обследования Шебекинского р-на Белгородской обл. (1971, 1991 гг.) выявлены изменения климатических показателей, отражающие внутривековые циклы Брикнера. Особенностью климатических изменений явилось нарастание среднегодовых температур воздуха (на $\left.0.2^{\circ} \mathrm{C}\right)$ и рост годового количества осадков (на 83 мм). На плакорных участках лугово-степных зональных ландшафтов выявлено нарастание площадей ареалов черноземов выщелоченных (Luvic Chernozems) и уменьшение площадей, занятых черноземами типичными (Haplic Chernozems).
\end{abstract}

Ключевые слова: черноземы, почвенный покров, лесостепь, Среднерусская возвышенность, изменение климата, метод ГИС-анализа, векторные карты.

DOI: $10.7868 / \mathrm{S} 0032180 \mathrm{X} 16070108$

\section{ВВЕДЕНИЕ}

В течение голоцена климат являлся определяющим фактором в эволюции почв. Долгопериодические флуктуации климатических изменений четко отражались на состоянии природных объектов, таких как торфяники, ледники, почвы. Однако на фоне вековых колебаний климата также существовали и короткопериодические изменения, которые могли не оставить следов в записях палеогеографических обстановок на этих объектах. Вместе с тем, Бергом [3] было обращено внимание на существенную роль короткопериодических изменений климата в функционировании и развитии природной среды. В его работах охарактеризована климатическая динамика в Европе в начале XX в., которая привела к определенным экологическим последствиям и обусловила изменение жизненных циклов и ареалов обитания многих организмов [3].

Клименко [11] привел анализ сезонного хода температур в южной половине Европейской равнины за период с 1891 по 1990 гг., в котором указано, что за этот столетний отрезок времени отмечались естественные колебания температуры летних и зимних сезонов, которые сопровожда- лись в 20-е-30-е и 70-е-80-е годы двумя крупными волнами похолоданий в летнее время и синхронных с ними волнами потеплений в зимнее время. Автор связывает это явление с резким возрастанием циклонической деятельности, которая привела к положительным аномалиям температуры в зимне-осенней части года, и к холодной и пасмурной погоде в теплой части года [11].

Дзердзеевским [6] был сформулирован прогноз циркуляционных и климатических условий для северного полушария на период до конца текущего столетия. В работе Сажина и Козиной [13] отмечается, что в северном полушарии в меридиональную эпоху циркуляции атмосферы (18901920 гг.) количество осадков превышало климатическую норму. С 1920 г. наступила зональная эпоха циркуляции, которая продолжалась до середины 1950 годов. После этого периода на юговостоке Европейской территории России устойчиво отмечалось увеличение увлажнения, достигшее максимума в 1990-2000 гг. [13].

Разуваев и Шаймарданов [14] характеризовали современную климатическую систему как непостоянную, вследствие изменчивости параметров климата. Такие климатические изменения при- 
водили к определенным последствиям, выражавшимся в изменении состава фитоценозов, повышении уровня грунтовых вод, понижении активности ветроэрозионных процессов [14].

В России за последние 10-15 лет возросла повторяемость засух на Европейской территории страны, существенно изменились климатические условия зимнего периода, что приводит к аридизации лесостепной и степной зон и, безусловно, сказывается на условиях сельскохозяйственного производства [9, 12].

Имеются указания на то, что в течение первой половины XXI в. развитие атмосферных процессов и связанных с ним режимов тепло- и влагообеспеченности будет происходить по аналогии с периодом 1920-1950 гг., что приведет к резкому ухудшению природно-климатических условий для развития земледелия на юге Восточно-Европейской равнины [18].

В ряде работ отмечается, что изменение климата может значительно влиять на почвы и их свойства. В частности, исследования, проведенные в центральной Канаде, показывают реакцию почвенного органического вещества на климатическую динамику [19]. Другой аспект, касающийся эрозии почв, связанный с количеством выпавших осадков в период 1989 по 2007 гг., был рассмотрен в статье немецких исследователей. Определив тренд климатических изменений, они разработали прогнозные модели до 2100 г., отражающие темпы эрозионных процессов почв [20].

Закономерности климатических изменений, отмеченные в литературных источниках, позволяют выявить влияние короткопериодических изменений климата на компоненты окружающей среды. Тем не менее, существует огромный дефицит сведений о влиянии внутривековых климатических циклов на почвы и почвенный покров. При этом изучение влияния изменений климата на почвы приобретает особенную актуальность в сельскохозяйственных регионах России.

В связи с вышесказанным, в данной работе предпринята попытка использовать материалы повторных почвенных обследований территорий для выявления ответной реакции зональных почв лесостепи в виде отдельных трансформаций почвенных ареалов на климатические изменения.

Современные методы исследований позволяют использовать для анализа почвенного покрова геоинформационные системы, которые дают возможность анализировать динамику почв на разных уровнях обобщения. Концепция компьютерного анализа динамики почвенных ресурсов мониторинга почв и разработки сценариев их возможных изменений была предложена Савиным [16]. Переход от традиционных почвенных карт к компьютерным базам данных открывает широкие возможности для оперативного обнов- ления существующих почвенных карт, а также для сопряженного анализа почвенно-ресурсной информации с информацией о рельефе, климате и других компонентах природной среды.

Цель нашего исследования заключалась в выявлении отклика почвенного покрова на юге лесостепи Среднерусской возвышенности на короткопериодические климатические изменения с использованием ГИС-технологий.

В задачи исследования входили:

- анализ метеорологических особенностей внутривекового климатического цикла, соответствующего периодам почвенных обследований в 1971 и 1991 гг.;

- выявление ответной реакции автоморфных черноземов юга лесостепи на климатическую изменчивость с применением ГИС-технологий по результатам данных разновременного крупномасштабного картографирования.

\section{ОБЪЕКТЫ И МЕТОДЫ}

На первом этапе выполнения исследований представлялось важным отработать технологию работы с материалами почвенных обследований территорий. Из архивных материалов Росреестра по Белгородской обл. был сформирован перечень районов, по которым имеются разновременные материалы почвенного обследования. Использовались карты масштаба 1 : 50000. Была проведена инвентаризация и составлен реестр крупномасштабных картографических материалов и почвенных описаний разных туров крупномасштабного почвенного картографирования. Выявлено, что из 21 административного района Белгородской обл. два тура почвенного обследования имеют всего 9 районов. Почвенные карты разных сроков составления по вышеуказанным территориям отразили состояние ареалов и площадей, занятых различными почвенными таксонами.

Для решения поставленных задач в качестве тестового объекта, на основе которого отрабатывались методические приемы работы с материалами повторных почвенных обследований, был выбран Шебекинский р-н Белгородской обл., расположенный в ее юго-западной части (на юге лесостепи Среднерусской возвышенности). Его общая площадь в современных административных границах составляет 184978 га. Шебекинский р-н входит в Среднерусскую лесостепную почвенную провинцию. Автоморфные почвы сформировались на лёссовидных суглинках и глинах, а местами - на выходах третичных глин и элювии мела.

Главные закономерности распространения почв связаны с рельефом и растительностью. Господство в прошлом (до начала XVII в.) двух зональных типов растительности - среднерусских дубрав и южного варианта лугово-разнотравных 
степей - обусловило формирование серых лесных почв (Luvic Greyzemic Phaeozems), черноземов оподзоленных (Luvic Greyzemic Chernic Phaeozem), выщелоченных и типичных. C особенностями рельефа связана вертикальная и экспозиционная дифференциация, а также эродированность почв [1]. Согласно результатам двух туров почвенных обследований (в 1971 и 1991 гг.), наибольшее распространение в Шебекинском р-не получили черноземы типичные и выщелоченные $[7,8]$.

Отклик почв на краткосрочные динамические изменения климата рассматривался в периоды различных фаз внутривекового климатического цикла. Были использованы результаты многолетних наблюдений климатических режимов Шебекинского p-на Белгородской обл., а также архивные материалы почвенного обследования вышеуказанного района, которые находятся в ведении управления Росреестра по Белгородской обл. Материалы почвенного обследования представлены двумя турами проведения работ и включают типовой набор документации: почвенный очерк, почвенная карта масштаба $1: 50000$, карты агропроизводственной группировки почв, а также эродированных земель и противоэрозионных мероприятий.

Первый тур почвенного обследования был проведен Белгородским филиалом института ЦЧО Гипрозем в 1971 г., второй тур - в 1991 г. В результате были составлены крупномасштабные почвенные карты в масштабе $1: 10000$ по землепользованиям хозяйств района с последующим уменьшением их до масштаба $1: 50000$ по исследуемому району в целом.

Для выполнения поставленных задач почвенные карты туров обследования были переведены в растровый слой.

Хитров с соавт. использовали некоторые подходы подсчета площадей различных категорий почв по электронным версиям карт. Этот методический прием касался обзорных почвенных карт [17]. В наших исследованиях работы проводились с крупномасштабными картами.

Анализ изменения границ почвенных контуров проводился на уровне подтипов лугово-степных черноземов. При этом был использован современный методический прием. С помощью геоинформационной системы ArcGIS (в программе ArcMap) почвенные карты были переведены в цифровой вариант. В результате этой работы были сформированы базы данных почвенных контуров и их площадей по турам обследования. Абсолютная ошибка определения площадей почвенных ареалов с учетом точности векторизации их контуров при обработке карт масштаба $1: 50000$ составила $400 \mathrm{~m}^{2}$ (0.04 га). Данная информация послужила исходным материалом для выявления различий в состоянии почвенного покрова между турами обследования. Автоматический подсчет площадей, занятых различными почвенными контурами, проводился с вычленением ареалов, различающихся по степени эродированности как не относящихся к плакорам. Кроме того, в программе ArcМар были выделены контуры почвенных ареалов не только типа и подтипа, но и более низких таксономических уровней - для возможности решения других задач, выходящих за рамки настоящего исследования. Поэтому при генерализации почвенные контуры не объединялись в автоматическом режиме, а оставались доступными для дальнейшего анализа.

Оцифрованная почвенная карта затем совмещалась с топографической основой для выявления принадлежности почвенных ареалов к плакорным территориям (с крутизной поверхности $0^{\circ}-2^{\circ}$ ).

При проведении работ следовало учесть, что результаты двух почвенных обследований основывались не на абсолютно идентичных классификациях и инструкциях. При проведении тура почвенного обследования в 1971 г. было рекомендовано использовать действующую на тот период времени инструкцию по крупномасштабным исследованиям территории колхозов и совхозов выпуска 1964 г. Последующий тур в 1991 г. проводился с учетом новых требований к классификации почв 1977 г. [10]. Поэтому на основании последнего тура обследования почв Шебекинского района данные 1971 г. были актуализированы в соответствии с действующей классификацией на момент последнего почвенного обследования.

\section{РЕЗУЛЬТАТЫ И ОБСУЖДЕНИЕ}

Из элементов климата в наибольшей степени на почвообразовательный процесс влияют осадки, испарение, температура, соотношение которых создает определенный тепловой и водный режимы развивающейся почвы.

На момент обследования почв были проанализированы климатические характеристики, усредненные по двадцатилетним интервалам (19511971 гг. и 1971-1991 гг.). Климатические условия на территории Шебекинского р-на характеризуются как умеренно-континентальные, что соответствует достаточно большой годовой амплитуде температур; сравнительно мягкой зиме с частыми оттепелями и снегопадами, жарким продолжительным летом, умеренным и не вполне устойчивым увлажнением с преобладанием летних осадков над зимними.

Безморозный период па территории района длится 153-164 дня. Начинается он в конце апреля и заканчивается в середине октября.

Последние весенние заморозки в воздухе наблюдаются в конце апреля (26.IV), первые осенние заморозки - в конце сентября (29.IX). На пониженных участках, куда стекают холодные массы 


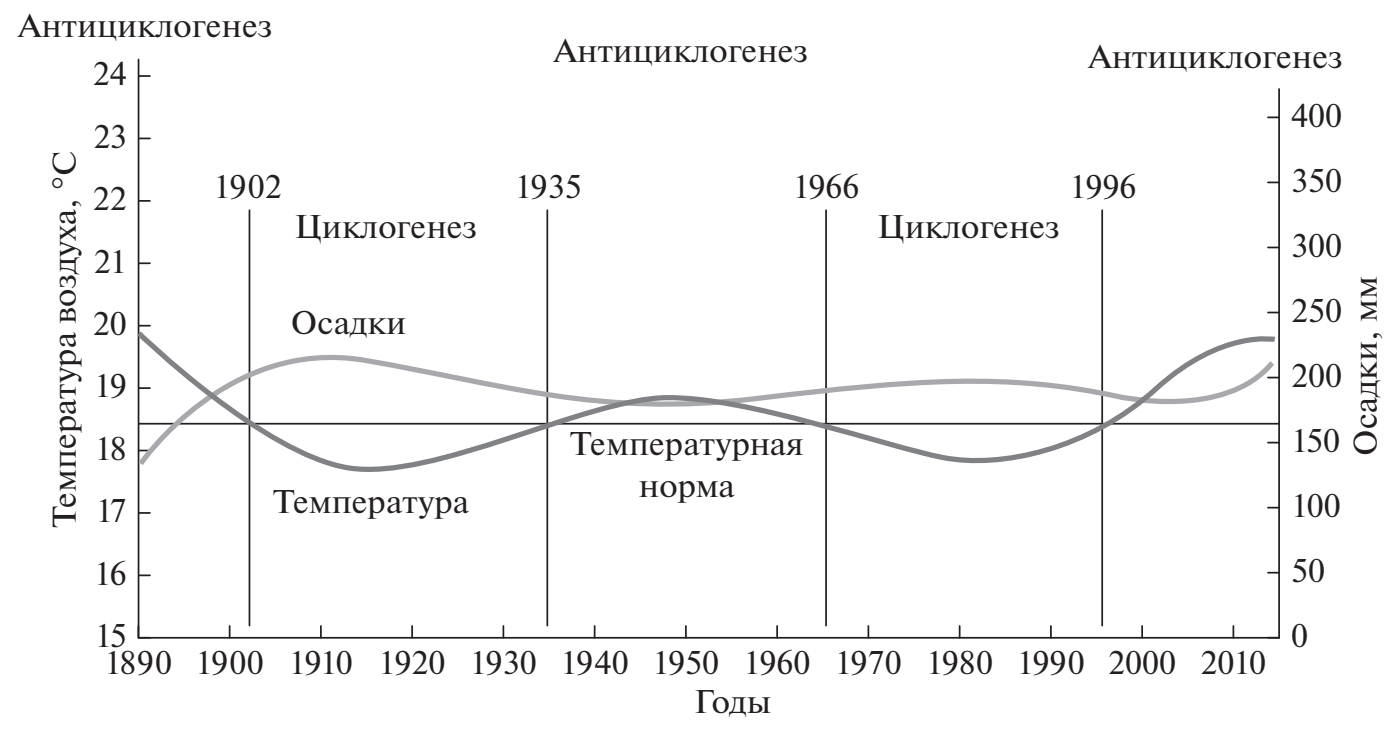

Рис. 1. Циклы Брикнера по данным полиномиального сглаживания хода средних летних температур воздуха и средних летних количеств атмосферных осадков (июнь-август) на метеостанции Богородицкое-Фенино.

воздуха, заморозки более часты и продолжительны. Наиболее холодным месяцем является январь, а наиболее теплым - июль. Число дней с температурой выше $0^{\circ} \mathrm{C}$ достигает 237 дней, выше $5^{\circ} \mathrm{C}-$ 197 дней, а выше $10^{\circ} \mathrm{C}-159$ дней. Переход температуры через $+5^{\circ} \mathrm{C}$ начинается с первой декады апреля и это время принято считать началом весеннего сезона. Продолжительность периода с температурой выше $+15^{\circ} \mathrm{C}$ может служить показателем наиболее благоприятных условий для возделывания теплолюбивых культур. Сумма положительных температур воздуха выше $10^{\circ} \mathrm{C}$ составляет $2600-2800^{\circ} \mathrm{C}$.

Согласно многолетним метеоданным за период с 1951 по 1971 гг., среднегодовая температура воздуха в районе исследования составляла $+6.3^{\circ} \mathrm{C}$, a среднегодовое количество осадков - 536 мм.

По данным метеорологических наблюдений за период с 1971 по 1991 гг. среднегодовая температура воздуха составила $+6.5^{\circ} \mathrm{C}$, а среднегодовое количество осадков - 619 мм.

Таким образом, при сравнении средних климатических показателей за периоды 1951-1971 и 1971-1991 гг. наблюдаются увеличение температуры воздуха на $0.2^{\circ} \mathrm{C}$ и увеличение годового количества осадков на 83 мм.

Есть все основания считать, что изменения указанных климатических параметров являются отражением внутривековой климатической цикличности, о чем свидетельствует волнообразный характер динамики средних летних температур воздуха и количеств атмосферных осадков по данным метеорологических наблюдений на станции Богородицкое-Фенино (рис. 1). Это старейшая метеостанция Белгородской обл. с непрерывным рядом наблюдений с 1881 г. Станция сохранила однородность и характерность рядов наблюдений по всем метеорологическим параметрам, репрезентативна и имеет статус "реперной климатической”.

На диаграмме рис. 2 представлен многолетний ход сглаженных нормированных отклонений средних летних и зимних температур воздуха и осадков на станции Богородицкое-Фенино за период 1900-2014 гг. Нормированные отклонения рассчитывались как отношение разности между фактическим и среднемноголетним значением к среднемноголетней величине показателей. Проанализировав данный ряд, можно сказать, что колебания температуры происходили с короткопериодической цикличностью. Период, предшествовавший первому почвенному обследованию (1971 г.), характеризовался температурами преимущественно ниже нормы, а период между турами обследования (1971-1991 гг.), в целом выше климатической нормы. Тренд осадков внутривекового периода наблюдений складывался в сторону их увеличения. Минимальные значения в ряду наблюдений отмечались в 1975 г. - 396 мм, 1984 г. - 486 мм и 1991 г. - 497 мм. За период между турами почвенного обследования указанные показатели также имели закономерную тенденцию роста в ряду многолетних наблюдений.

На рис. 3 для подтверждения указанных выше климатических изменений также приводятся данные по осадкам и температуре по ближе расположенным к Шебекинскому р-ну метеорологическим станциям Белгородской области - Белгород и Готня с 1944 по 2014 гг. Анализ полученных графиков отражает волнообразное движение кривых нормированных отклонений сумм атмо- 

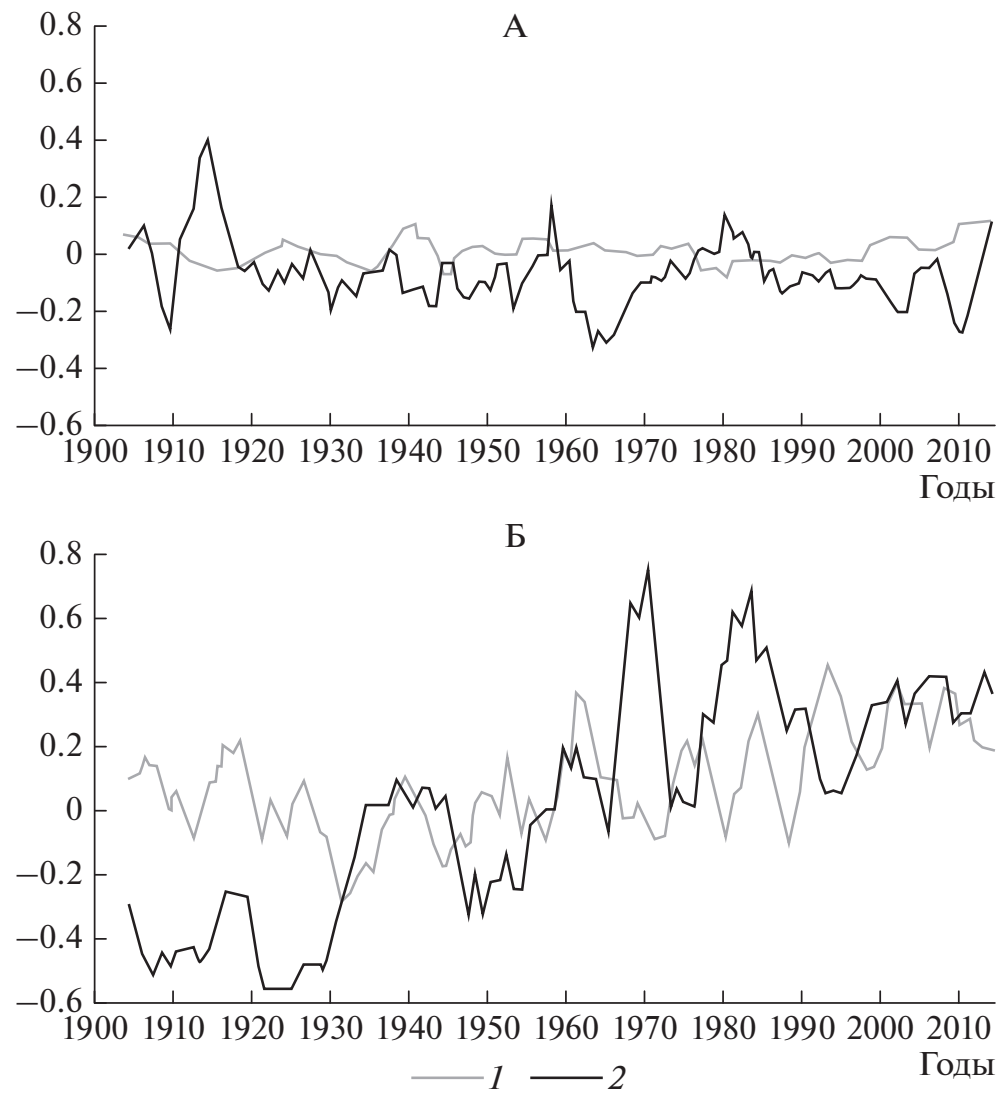

Рис. 2. Сглаженные нормированные отклонения сумм осадков (1) и температуры воздуха (2) за период 1900-2014 гг. по данным метеорологической станции Богородицкое-Фенино (линейный фильтр - 5 лет): А - лето; Б - зима.

сферных осадков, которые подчиняются следующей закономерности: с 1944 по 1969 гг. наблюдаются значения ниже климатической нормы, затем, до второго тура почвенного обследования 1991 г., соответствующие показатели увеличиваются, достигая максимальных величин.

Наблюдавшееся увеличение количества атмосферных осадков, по нашему мнению, должно было отразиться на глубине промачивания почвенного профиля, что закономерно должно привести к изменению морфологических свойств почв и, в частности, глубины вскипания.

Еще в конце XIX в. Брикнером и Воейковым была выдвинута гипотеза о циклических изменениях климата - чередовании прохладновлажных и тепло-сухих периодов через каждые 35-45 лет [18]. Выявленная нами волнообразная динамика метеорологических данных по станции Богородицкое-Фенино подтверждает чередование фаз циклогенеза и антициклогенеза в соответствии с циклами Брикнера и представлениями Клименко [11] (рис. 1). Периоду, предшествовавшему первому почвенному обследованию (1971 г.), соответствовала фаза антициклогенеза, а второму почвенному обследованию (1991 г.) - фаза циклогенеза (рис. 1).
При рассмотрении территории Белгородской обл. в целом, за 20-летний период, с 1971 по 1991 гг., прослеживается увеличение годового количества осадков (рис. 4). Такая климатическая особенность, по нашему мнению, должна была отразиться на изменениях контуров почвенных ареалов. Согласно рабочей гипотезе, внутривековая климатическая изменчивость за исследуемый 20-летний период, выражающаяся в росте увлажненности, должна была привести к увеличению выщелачивания почв и к закономерному росту площадей, занятых черноземами выщелоченными.

На высокую динамичность поведения карбонатных профилей черноземов, обусловленную климатической изменчивостью, указывает ряд авторов. Так, Геннадиев отмечал, что “...повышенное количество жидких летних и зимних осадков при достаточной длительности периода с биологически активными температурами обеспечивает, с одной стороны, частое и глубокое промачивание почвы, ведущее к нисходящему растягиванию карбонатов по профилю и слабой выраженности максимума содержания этих соединений, с другой - периодическое возникновение восходящих токов влаги, несущих к поверхности углекислые соли” [4, стр. 136]. Это указывает на мобильность 

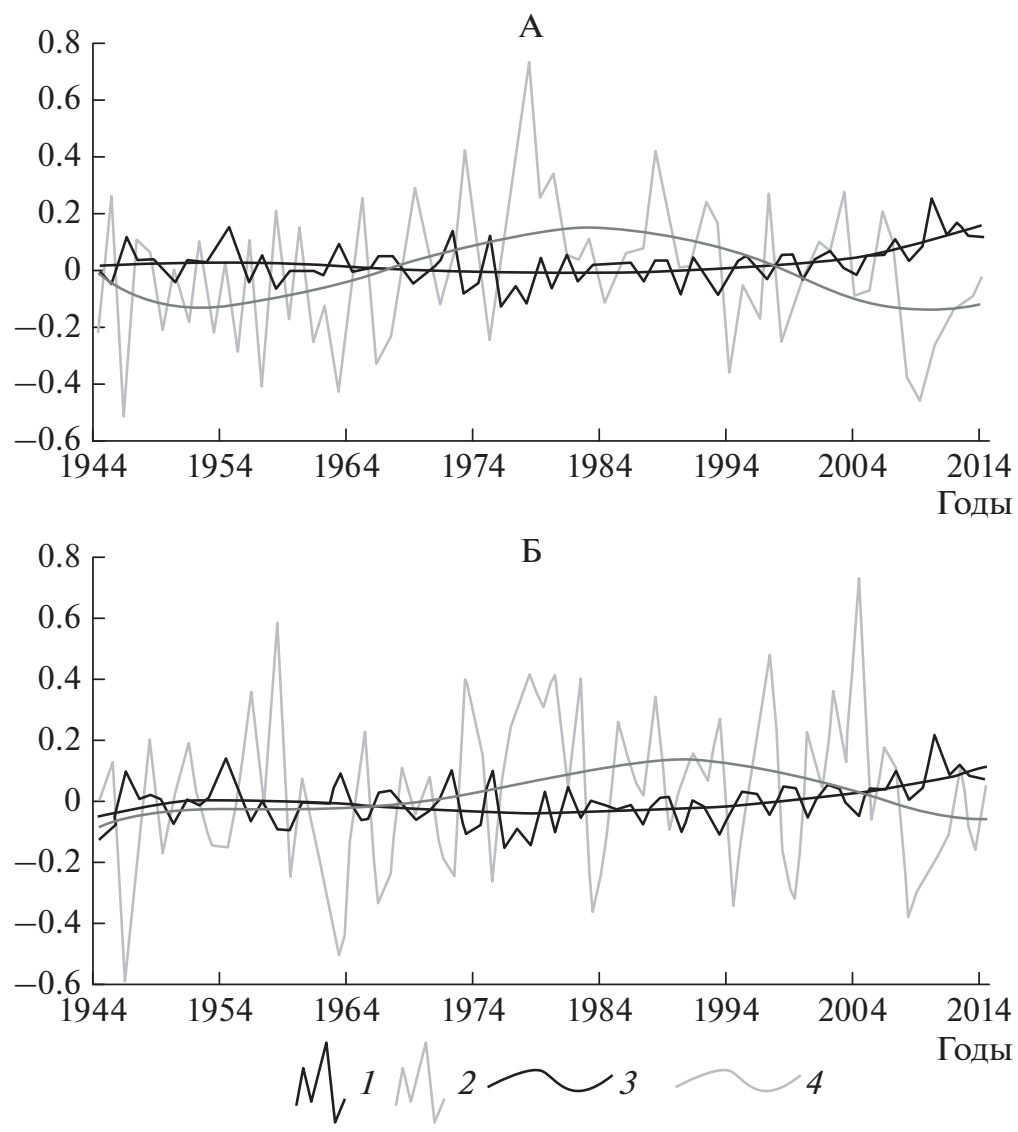

Рис. 3. Графики нормированных отклонений сумм осадков и температур (май-сентябрь) по данным метеорологических станций: А - Белгород; Б - Готня; 1 - нормированные аномалии температуры; 2 - нормированные аномалии осадков; 3 - полиномиальный тренд температуры; 4 - полиномиальный тренд осадков.

карбонатных солей в процессе климатических трансформаций черноземов. Исследования сезонной динамики линии вскипания в луговостепных черноземах на территории Среднерусской возвышенности также показывают высокую степень отзывчивости данного показателя на атмосферное увлажнение [2].

Исследования Герцык и Роде, проведенные в 1970-х гг., показали, что наблюдающееся в этот период нарастание атмосферного увлажнения повлекло за собой изменение режима влажности черноземов, увеличение в них запасов влаги, более частое сквозное промачивание трехметровой почвенной толщи, а также изменение их карбонатного профиля и ряда диагностических признаков [5].

В соответствии с результатами исследования Рогожниковой [15], на территории Каменной Степи в течение последних десятилетий также отмечалась трансформация черноземных почв в условиях повышенного атмосферного и грунтового увлажнения. При этом переувлажнение и подтопление привело к изменению ряда свойств черноземов, в том числе к усилению процессов декальцификации (вынос карбонатов кальция).
В частности, вынос карбонатов может приводить к обеднению почвенных растворов кальцием, смещению обменных реакций между ППК и почвенным раствором в сторону уменьшения доли обменного кальция [15].

Для подтверждения гипотезы об увеличении в структуре почвенного покрова доли выщелоченных черноземов в период с 1971 по 1991 гг. выполненные нами электронные версии почвенных карт Шебекинского района за указанные годы обследования были совмешены в системе ArcGIS. По полученным данным из ArcGIS была сформирована таблица, в которой по почвенным таксонам в соответствии с легендами карт были получены сведения о расхождениях площадей почвенных ареалов при наложении карт разного времени обследования.

Из анализируемых площадей были исключены определенные части территории Шебекинского р-на ввиду произошедших за 20 -летний период изменений. Существующее расхождение в площадях района исследования (1971 г. - 184978 га, 1991 г. - 185914 га) объясняется, по крайней мере, двумя причинами: появлением на карте 1991 г. Белгородского водохранилища, и соответственно 

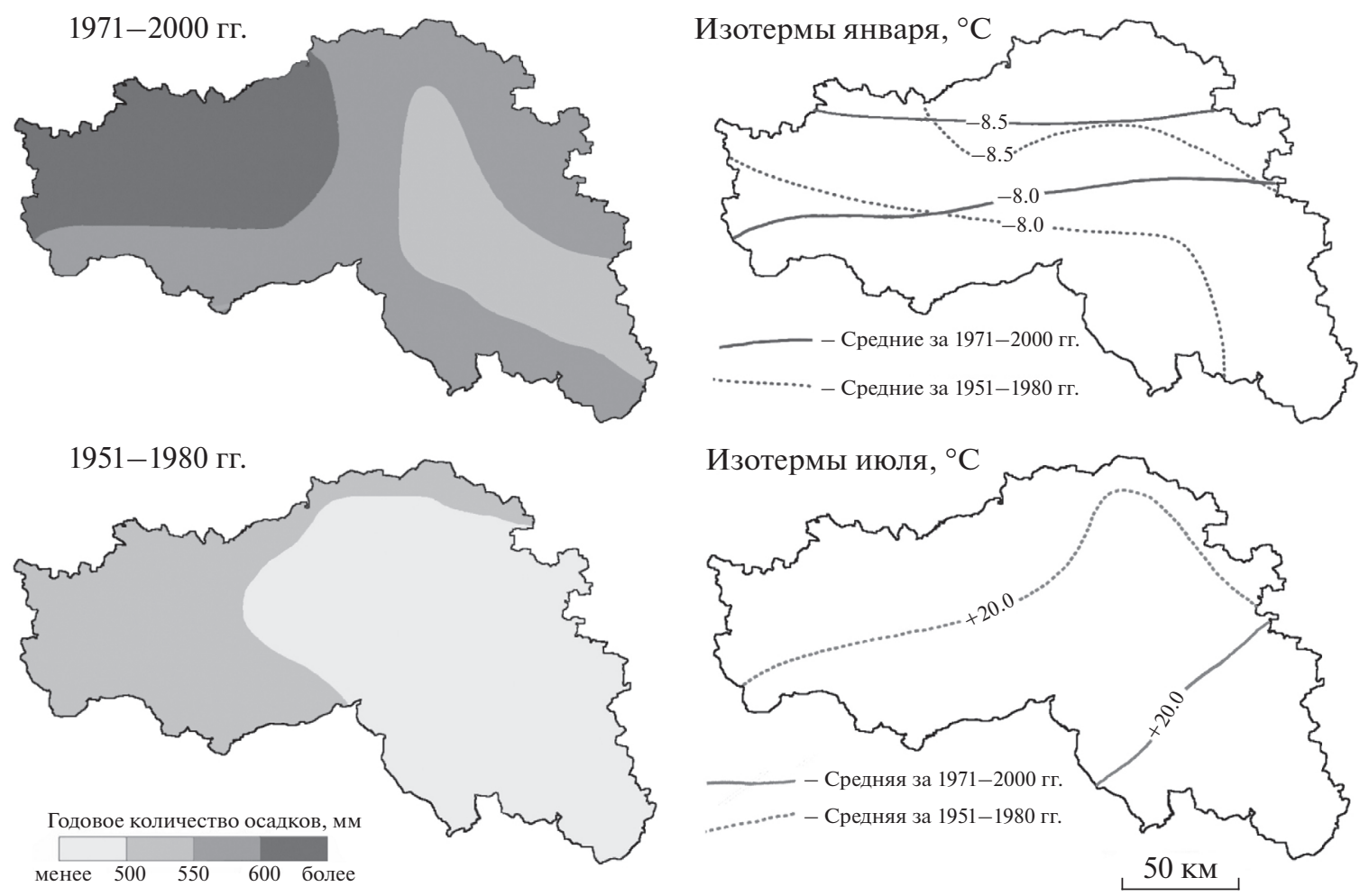

Рис. 4. Климатические показатели Белгородской обл. в различные периоды (1951-1980 гг., 1971-2000 гг.) [21].

затоплением части территории, а также передачей отдельных сельскохозяйственных предприятий в состав соседних Корочанского и Белгородского р-нов.

Как и ожидалось, при анализе разновременных почвенных карт достаточно характерным явлением оказалось уменьшение площадей черноземов типичных и увеличение площадей, занятых черноземами выщелоченными, как, например, в северной части Шебекинского р-на, взятой нами в качестве модельного ключевого участка. Рис. 5 передает исходный картографический материал в виде фрагментов карт двух туров почвенного обследования. На рис. 6 приведены фрагменты данных каждому почвенному ареалу. На следующем этапе работы ГИС-анализ предполагал выделение элементов почвенного покрова в виде полигонов черноземов выщелоченных и типичных на плакорных участках местности в соответствии с поставленной целью исследования (рис. 7).

Используя геопространственный анализ (инструмент "Пересечение" программ ArcGIS), были оценены площади совпадающих контуров черноземов выщелоченных и типичных и их трансформация. В пределах модельного ключевого участка в 1991 г. по сравнению с 1971 г. выявлено увеличение площадей выщелоченных черноземов на 191 га или в 2 раза от их площади в 1971 г. и закономерное уменьшение площадей, занятых черноземами типичными (таблица).
Полученные результаты по изменению почвенных контуров с помощью ГИС-программы дали возможность установить произошедшие изменения в структуре почвенного покрова. Геоинформационная система ArcGIS, по нашему мнению, может рассматриваться в качестве достаточно эффективного инструментария для такого рода задач. Достоинством этого метода является автоматическое формирование баз данных, включающих подробную атрибутивную информацию, характеризующую морфологические, физические, физикохимические и химические свойства почв.

Использование программы ArcМap частично снимает проблему оценки точности сравнения разновременных карт, которые приводятся к еди-

Изменение площадей почвенных ареалов на плакорных участках презентабельного фрагмента карты в ArcGIS по материалам двух туров крупномасштабного картографирования

\begin{tabular}{l|l|c}
\hline \multicolumn{1}{c|}{ Почвы } & \multicolumn{1}{|c|}{ Годы } & \multicolumn{1}{|c}{$\begin{array}{c}\text { Площади } \\
\text { почв, га }\end{array}$} \\
\hline Черноземы & 1971 & 190 \\
выщелоченные & 1991 & 381 \\
& Разность 1991-1971 & 191 \\
Черноземы & 1971 & 555 \\
типичные & 1991 & 427 \\
& Разность 1991-1971 & 128 \\
\hline
\end{tabular}


A

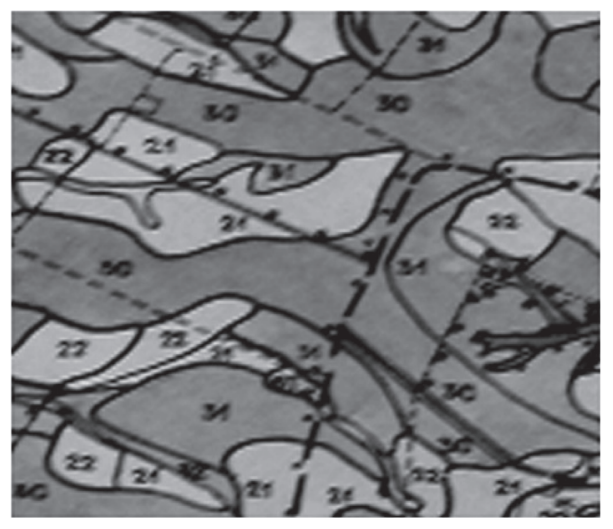

Б

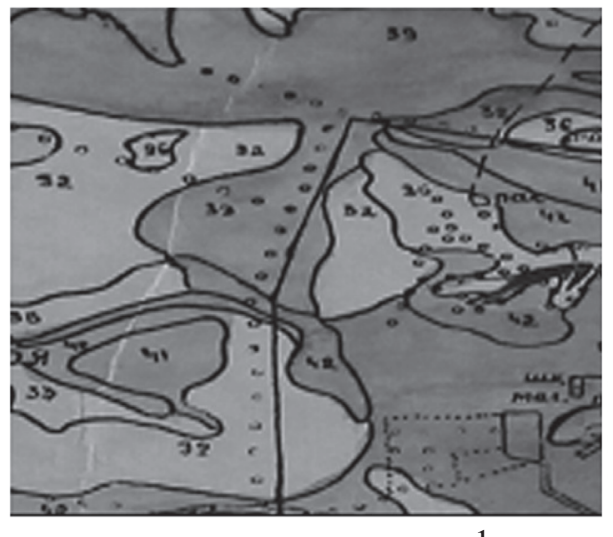

Рис. 5. Сканированные фрагменты разновременных почвенных карт Шебекинского р-на Белгородской обл. (модельный ключевой участок) - первый (А) и второй (Б) туры почвенных обследований.
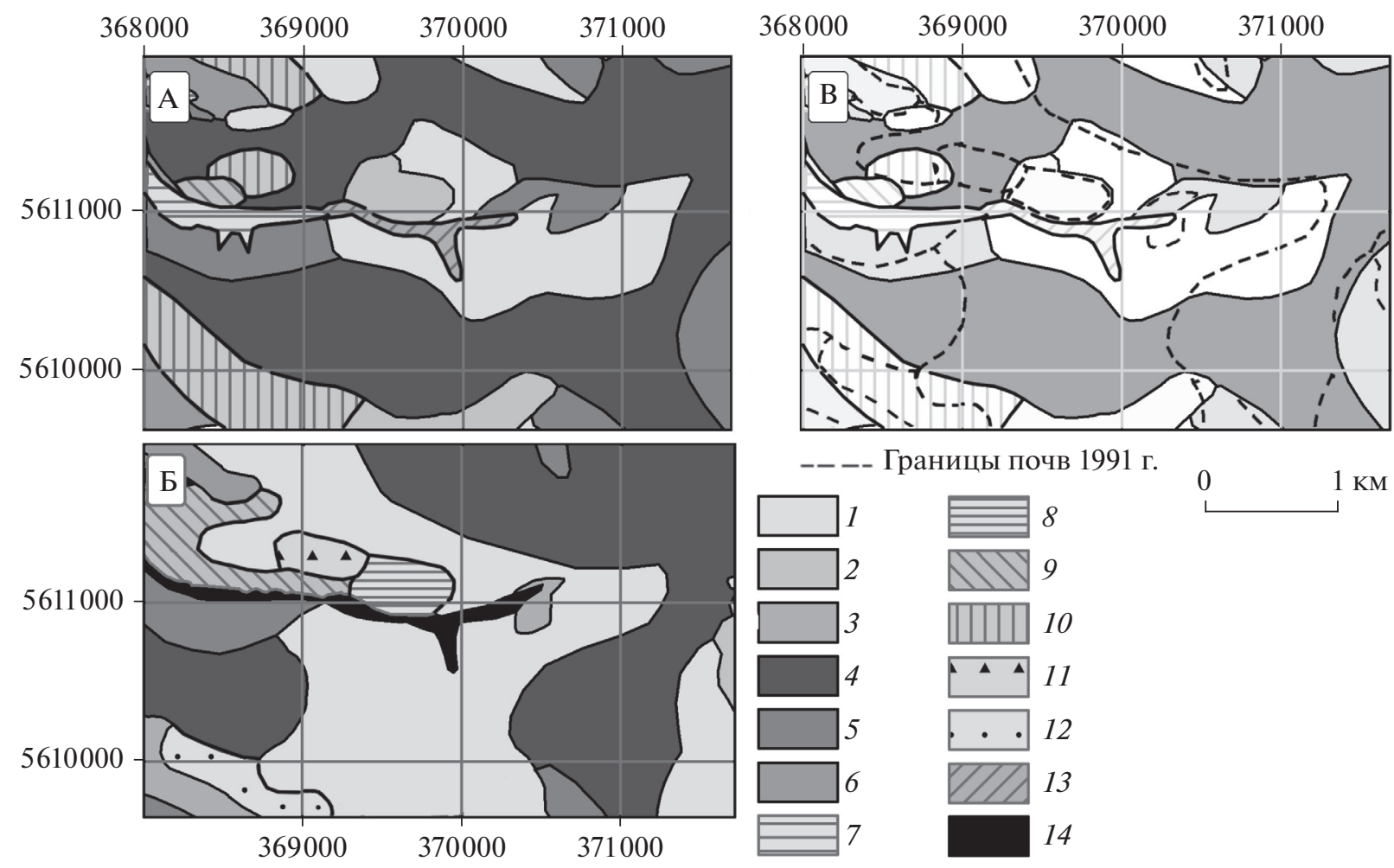

Pис. 6. Фрагменты разновременных почвенных карт Шебекинского района Белгородской обл. в ArcGIS. A - 1971 г.; Б - 1991 г.; В - наложение почвенных контуров двух туров обследования. Обозначения почв: 1 - черноземы выщелоченные; 2 - черноземы выщелоченные слабосмытые; 3 - черноземы выщелоченные среднесмытые; 4 - черноземы типичные; 5 - черноземы типичные слабосмытые; 6 - черноземы типичные среднесмытые; 7 - черноземы типичные карбонатные; 8-черноземы типичные карбонатные слабосмытые; 9 - черноземы типичные остаточно-карбонатные; 10 - черноземы типичные остаточно-солонцеватые; 11 - черноземы среднесолонцеватые слабосмытые; 12 - солоди глееватые; 13 - балочные черноземы выщелоченные сильносмытые; 14 - выходы пород.

ной картографической основе, устраняя погрешности субъективного характера, обусловленные работой разных картографов в разные годы. Поэтому наложение оцифрованных и привязанных по космоснимку карт разных туров почвенного об- следования дает репрезентативную информацию о площадях ареалов почв и их изменении во времени. Возможность оперативного расчета площадей почвенных ареалов на оцифрованных картах с помощью программного обеспечения сводит к мини- 


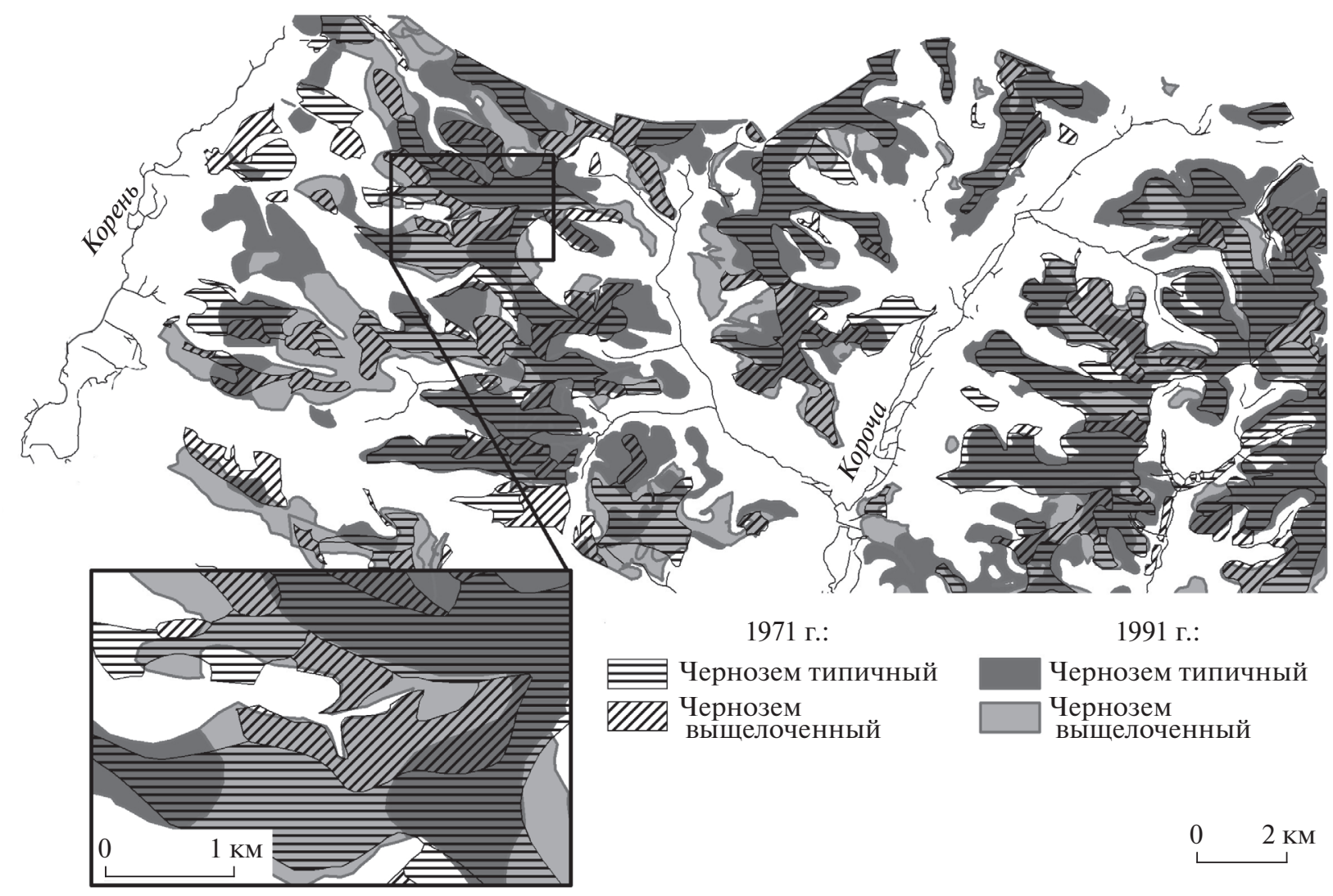

Рис. 7. Результаты геопространственного анализа ареалов черноземов выщелоченных и типичных на плакорах в программе ArcGIS. Модельный полигон исследования выделен рамкой.

муму субъективный подход при интерпретации результатов фрагментарного исследования презентабельных, с точки зрения исследователя, участков.

Использование геоинформационной системы ArcGIS для обработки данных позволило получить информацию как качественного характера визуализированную трансформацию почвенного покрова на разновременных почвенных картах, так и количественную информацию по площадям вследствие четкой пространственной привязки контуров почвенных ареалов разновременных карт для их сравнительного анализа.

Безусловно, интерпретация результатов может быть дискуссионной из-за слабой разработки вопросов, касающихся возможности быстрых изменений почвенных ареалов как отклика на короткопериодическую динамику климата, а также различных подходов к диагностике и идентификации почв в полевой и камеральный периоды крупномасштабного почвенного картографирования.

В данных исследованиях наметились определенные закономерности, которые требуют более детального рассмотрения вопросов, связанных с выявлением откликов почв на климатическую изменчивость. Для отработки предложенных методических подходов на смежных территориях, обеспеченных материалами повторных почвенных обследований, планируется провести формирование баз данных почвенных контуров и их площадей по турам обследования с использованием геоинформационных систем. Будут составлены ряды сравнения свойств почв на изучаемых территориях.

В перспективе могут быть определены участки почвенного покрова, наиболее ярко реагирующие на климатическую динамику, и разработаны рекомендации по их мониторингу и рациональному использованию с учетом региональных особенностей землепользования.

\section{ВЫВОДЫ}

1. За период между двумя турами крупномасштабного почвенного обследования Шебекинского р-на Белгородской обл. выявлены изменения климатических показателей, отражающие внутривековой цикл Брикнера, подкрепленный рядами метеорологических наблюдений на метеостанциях Белгородской обл., включающих одну из старейших станций в России - станцию Богородицкое-Фенино. С 1971 по 1991 гг. происходило нарастание положительных температур 
воздуха при увеличении годовых количеств атмосферных осадков: среднегодовая температура повысилась на $0.2^{\circ} \mathrm{C}$, а среднегодовое количество осадков возросло на 83 мм, то есть континентальность климата уменьшилась.

2. С использованием программы ArcGis созданы разновременные почвенные карты масштаба $1: 50000$ в растровом и цифровом виде, позволившие получить сведения о динамике площадей ареалов типичных и вышелоченных черноземов в пределах плакорного типа местности. На модельном ключевом участке исследования за 20-летний период было выявлено увеличение площадей, занятых черноземами выщелоченными на месте существовавших ранее черноземов типичных.

3. Комплекс работ по инвентаризации и подготовке реестра крупномасштабных картографических материалов и почвенных описаний разных туров почвенного обследования, соответствующих периодам различных фаз внутривековых гелиоклиматических циклов дал, возможность сформировать электронную базу данных почвенных ареалов изучаемой территории, что может рассматриваться как начальный этап дальнейшего анализа многолетних изменений показателей состояния почвы и их плодородия на территории Белгородской обл. Работа с программой ArcGIS позволяет с высокой точностью использовать приемы сравнительного анализа разновременных почвенных карт крупного масштаба как инновационное приложение в системе почвенно-экологического мониторинга.

Благодарность. Исследование выполнено при поддержке Российского научного фонда (проект № 14-17-00171) на тему: "Региональные отклики компонентов окружающей среды на изменения климата разной периодичности: юг лесостепи Среднерусской возвышенности”.

\section{СПИСОК ЛИТЕРАТУРЫ}

1. Ахтыриев Б.П., Соловиченко В.Д. Почвенный покров Белгородской области: структура, районирование и рациональное использование. Воронеж: Изд-во ВГУ, 1984. 268 с.

2. Афанасьева E.A. Черноземы Среднерусской возвышенности М.: Наука, 1966. 227 с.

3. Берг Л.С. Климат и жизнь. М.: Огиз-Географгиз, 1947. $356 \mathrm{c}$.

4. Геннадиев А.Н. Почвы и время: модели развития. М.: Изд-во Моск. ун-та, 1990. С. 136-137.

5. Герцык B.B., Роде A.A. Элементы баланса влаги в целинных черноземах в некосимой степи и дубовом лесу // Почвоведение. 1978. № 7. С. 77-86.

6. Дзердзеевский Б.Л. Общая циркуляция атмосферы и климат. Избранные труды. М.: Наука, 1975. 288 с.
7. Дудников И., Стрельников М., Карнаух В., Белевцов И., Соловиченко В., Пстыкун А., Павлова Л. Почвы Шебекинского района Белгородской области и рекомендации по их использованию. Белгород: Белгородский филиал института ЦЧОНИИ Гипрозем, 1975. 133 с.

8. Дудников И.А., Зверев Г.М., Посохова Л.В. Почвы Шебекинского района Белгородской области и рекомендации по их использованию. Белгород: Белгородское предприятие института ЦЧОНИИ Гипрозем, 1994. 173 с.

9. Изменение климата. Обобщенный доклад об оценке Межправительственной группы экспертов по изменению климата / Под ред. Р.Т. Уотсона. ВМО, ЮНЕП, 2001. 215 c.

10. Классификация и диагностика почв СССР. М.: Колос, 1977. 224 с.

11. Клименко Л.В. Колебания температуры воздуха на южной половине Европейской территории СССР в 1891-1990 гг. // Вестн. Моск. ун-та. Сер. 5. География. 1992. № 1. С. 25-30.

12. Менжулин Г.В., Савватеев С.П. Мировая продовольственная проблема и современное глобальное потепление // Изменения климата и их последствия. СПб: Наука, 2002. С. 122-151.

13. Сажин А.Н., Козина О.В. Современные климатические тенденции и их отражение на региональном уровне (на примере Нижнего Поволжья) // Научное познание окружающего мира, динамика географической среды (природа, общество, политика). Тр. ХІ съезда РГО. СПб, 2000. Т. 5. С. 105-106.

14. Разуваев В.Н., Шаймарданов М.3. Меняющийся климат планеты. М.: Модус К-Этерна, 2005. 320 с.

15. Рогожникова E.В. Состояние карбонатов в черноземах Каменной Степи. Дис. ... канд. биол. н. М., 2010. $158 \mathrm{c}$

16. Савин И.Ю. Анализ почвенных ресурсов на основе геоинформационных технологий. Автореф. дис. ... Д-ра с./х. н. 03.00.27. М., 2004. 47 с.

17. Хитров Н.Б., Рухович Д.И., Калинина Н.В., Новикова А.Ф., Панкова Е.И., Черноусенко Г.И. Оценка площадей засоленных почв на территории Европейской части России (по электронной версии карты засоления почв масштаба $1: 2.5$ млн) // Почвоведение. 2009. № 6. С. 627-637.

18. Чендев Ю.Г., Петин А.Н. Изменения климата $\mathrm{XX}$ столетия и их влияние на почвенный покров // Изменения климата, почвы и окружающая среда: материалы Междунар. науч. семинара, г. Белгород, 16-19 сентября 2009 г. Белгород: КОНСТАНTA, 2009. C. 147-155.

19. Purton K., Pennock D., Leinweber P., Walley F. Will changes in climate and land use affect soil organic matter composition? Evidence from an ecotonalclimosequence // Geoderma. 2015. V. 253-254. P. 48-60.

20. Routschek A., Schmidt J., Kreienkamp F. Impact of climatechange on soil erosion - A high-resolution projection on catchment scale until 2100 in Saxony/Germany // Catena. 2014. V. 121. P. 99-109.

21. Chendev Yu.G., Petin A.N., Lupo A.R. Soils as indicators of climatic changes // Geography, Environment, Sustainability. 2012. № 1. P. 4-17. 